\title{
The Analysis of Legal Environment and Administrative Burden of SMEs as an Obstacle to Business
}

\author{
Iveta Kmecová1, Michal Tlustý1, Vendula Velková ${ }^{1}$ \\ ${ }^{1}$ Institute of Technology and Business in České Budějovice, Faculty of Corporate \\ Strategy, Czech Republic
}

\begin{abstract}
The paper outlines the problematic areas of legal environment and administrative load that are identified especially by the means of research of SME. The theoretical part deals with the issue of administrative burden of businesses. The part of methodology presents the basic systems of statistical calculations and hypothesis. Attention is paid to the assessment of the intensity of business administration in the area of small and middle-sized enterprises. The businesses are divided in accordance of various criteria (business size in accordance of the number of employees, the size of achieved turnover, sector, tax burden) and hypothesis are set, confirmed or rejected by using t-tests and other criteria, subsequently, the results are compared. The main purpose is to prove that small and medium-sized enterprises are overloaded by demanding business administration and taxation, and that it is important to examine the issue in greater depth. The aim of the paper is to determine, by the means of statistical methods, whether the businesses are excessively taxed by demanding business administration and, eventually, to compare the achieved results.
\end{abstract}

Keywords: legal environment, administrative burden, administrative intensity, small and middle-sized enterprises, one-sample t-test

\section{Introduction}

The issue of legal base in businesses and the related administrative burden attracts the attention of many experts. The legal base and administrative burden of businesses were significantly influenced by joining the European Union by the Czech Republic on 1sth May 2004 (Kmecova and Bilek, 2020). 
It was a threat for some SMEs on one hand, while it meant new opportunities for other businesses on the other hand. The reason was the ongoing changes in Czech legal rules and other sources, the competitive arrangement and the new legislative arrangement. Businesses have to deal with this situation and struggle with it. The business environment is one of the summary aspects for the development and existence of business activity. We can understand it as a set of tools and factors whose effect on the business improves its competitiveness and growth potential. It is still difficult for SMEs to adopt the principles of a new business environment on a European scale. These businesses must respect the same legislative and administrative requirements as large businesses. Unfortunately, small and medium-sized enterprises cannot sufficiently cope with it, because large enterprises solve problems by delegating activities to a number of internal specialists. A good solution for small and medium-sized enterprises in the future could be, for example, cooperation with external experts or the application of an effective information system to reduce the administrative burden by creating a manual. It is necessary to create favourable conditions for business, because the importance of the small and mediumsized enterprise sector is obvious for the Czech economy (MIT, 2018). For some SMEs this posed a threat on the one hand and new opportunities for other businesses on the other.

\section{Theoretical Background}

Business in the Czech Republic is legislatively regulated at the general level by numerous pieces of legislation and rules. Administrative burden imposed on the businesses gradually grows every year. The issue of administrative burden is dealt with by numerous authors not only in the Czech Republic but also abroad.

Braunerhjelma and Eklunda (2014) examine the tax administrative burden and its impact on the creation of a new business. Moynihan et al. (2015), offers two theoretical perspectives. The first perspective: the administrative burden, as an important variable in understanding how citizens experience the state. Administrative burden is conceived as a function of the costs of learning, psychology and compliance that citizens experience in their interactions with the government. The second perspective: the authors argue that the administrative burden is a place of politics.

Veiga et al. (2016) examined the impact of administrative burden on costs for businesses, citizens and the administration itself related to the compliance with the decrees of the government and procedures. The results showed that the burden tends to increase with new forms of public administration. Hodinkova and Svirak (2014) focused on the development of small and medium-sized enterprises (SMEs) operating in the Czech Republic. The main goal was to evaluate the current situation of SMEs in the Czech Republic, identify the main obstacles to their development and propose measures to eliminate them. Zarova (2010) deals with the current revisions of the Fourth and Seventh EC (European Community) Directives, which are taking place as part of the process of simplifying accounting rules for small and medium-sized enterprises. The author mentions that the aim of the revision of the accounting guidelines is to modernize and 
simplify reporting requirements, as well as their comprehensibility and accessibility. The revision follows the motto "think small units first". The Commission's regulatory strategy aim is to measure administrative costs and reduce administrative burden. Ropret, et al. (2018) present the results obtained from a comprehensive analysis of the key administrative barriers that SMEs face in Slovenia. These include three activities: (1) identifying the main areas where obstacles occur; (2) determining what performance means; and (3) providing guidance for policy makers adapted to different groups of SMEs. Empirical results on a sample of 925 SMEs show differences in the different groups of SMEs mentioned above. The results show that it is appropriate to address administrative barriers through an in-depth approach that focuses on specific groups of companies and is reflected in the guidelines for responsible policy makers. Sarah et al. (2018) identified administrative barriers to inland waterway transport on the Danube and developed solutions for improved procedures and processes. National focus groups were set up to analyse procedures and administrative processes within the inland waterway transport and to identify administrative barriers. Therefore, many administrative barriers were identified in the countries along the Danube. Then Port Community Systems was presented as a possible solution to overcome administrative barriers.

According to Ntaliani and Costopoulou (2018), reducing administrative burdens is part of the political agenda in European countries and international organizations. The aim of the research was to measure the administrative burden of rural businesses. The main finding was that rural businesses do not perceive the administrative burden on business very positively; public administrations could introduce semantic eGovernment services to reduce the administrative burden on rural businesses; and future policies to reduce administrative burdens should take into account the type and location of businesses in order to achieve an efficient business environment.

The governments practice policies to reduce administrative burden especially for small businesses in order to increase their flexibility and vitality. The aim is the reduction of administrative burden. The paper by Ntaliani and Costopoulou (2017) presents a European initiative that uses a method of measuring the costs incurred on SMEs that occur in the course of seeking information for the public service. The research results provide guidance to policy makers and decision-makers in dealing with the administrative burden on businesses in the information phase of public services. Cepel (2018) defined and quantified significant factors that shape the quality of the business environment in the SME segment and created the quality index of business environment. A part of the aim was to compare defined factors in the Czech Republic and in Slovakia. With regard to the defined aim, a research was conducted on the basis of a previous research in businesses operating in the SME segment. The results showed the fact that the Slovak businesses do much better in every factor of the research that the businesses in the Czech Republic.

The state can help the entrepreneurs in their activities by a business environment or it can impose a burden on them. The aim of the research (Vieglerova et al., 2016) was to find out how the entrepreneurs of small and middle-sized enterprises (SME) in the Czech 
Republic perceive the role of the state and its influence on business. It was discovered that small and middle-sized enterprises perceive the assistance of the state more than microbusinesses. More than 53\% of entrepreneurs came up against patronage. The results further confirmed that the issue of corruption intensifies with the size of a business. Fighting corruption and patronage can be significantly more affected by the length of doing business than the size of a company.

There is another research stating that excessive bureaucracy, administration and frequent legislative amendments are some of the current factors deterring people from becoming entrepreneurs. The main aim was to present scientific evidence that gender is one of the factors with a significant impact on the management of administrative activities of a company and on the company's perception of administrative burden such as bureaucracy and frequent tax changes and legal amendments. The results were as follows: young men and women consider various areas of bureaucracy to be excessive; women entrepreneurs spend more time monitoring changes in legislation affecting the business environment, and women spend almost twice as much time on administrative activities. (Kljucnikov and Majkova, 2016).

According to Fifka and Adaui (2015), CSR reporting has recently received full attention in the business community thanks to the implementation of CSR reporting at the EU level. In this context, there is an intense debate about whether companies should not be forced to report on their social and environmental results. This response clearly reflects the widespread notion that CSR reporting is an administrative and financial burden, and supports the need for laws to implement it.

All businesses are inseparably linked to the business environment, which significantly influences their performance. In this respect, the state is one of the most influencing factors. It also has many other roles that can appear useful or harmful in the eyes of the business owner, for instance, setting the legislative framework for business, setting the conditions for starting business and regulating competition. It was found, according to Kamil et al. (2017), that entrepreneurs are very critical of the role of the state in business environment; in particular, $60 \%$ of respondents do not agree that the state creates favourable conditions for business in the Czech Republic.

\section{Methods and Data}

In this paper, we aim to confirm or reject the claim that small and medium-sized enterprises are overburdened with administrative obligations in their business and to compare the results of intensity of business administration according to various measures (company size, turnover, sector of operation, etc). The research is based on a questionnaire survey. 


\section{The methods of data collection}

Primary data for legal area and for the intensity of administration were obtained by the means of questionnaire survey in SMEs. It was an online questionnaire: legal and administrative intensity of business. The questionnaire was created by using the tool of Google Apps - Questionnaires. The return rate of the questionnaires was 35\% (out of 500 SMEs). It was 175 questionnaires in total. The structure of research sample is summarily shown in graph 1.

Graph 1: Structure of research sample

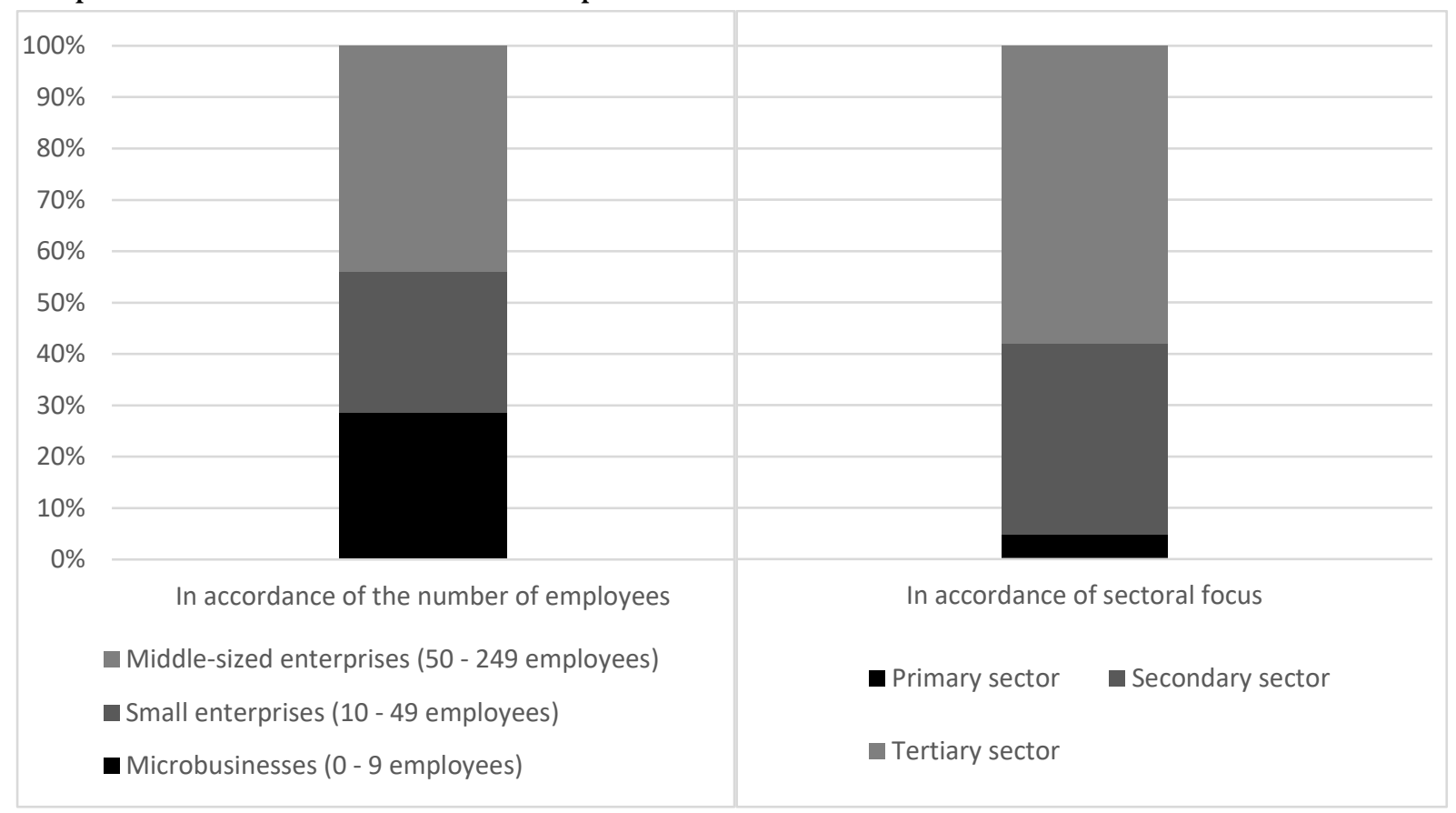

Source: Authors.

The data for the processing of the research were divided. The main criteria were the base from which the practical part was developed. The main criterion was the division of SMEs into small enterprises (less than 50 employees) and middle enterprises (from 50 employees to 250 employees). Further division was based on the achieved SMEs' turnovers the last divisional group was based on the sectors where the businesses operate. Due to the small number of businesses operating in the primary sector, we merged these businesses into one group, together with the secondary sector. The second group was the tertiary sector; businesses providing services.

\section{The Methods of Data Assessment}

For the analysis of the obtained data set, for our paper, we chose a one-sample t-test. This calculation tests, or compares, the mean values of one file that contains data on the same principle. This means that the data must be equally distributed, for example from one measurement but from various respondents (Dalgaard, 2008). 
It is important to set the essential indicators for basic statistical assessment. The first main indicator is a simple arithmetic mean. The calculation of this quantity is as follows (Budikova et al., 2010).

$$
\bar{x}=\frac{1}{n} *\left(x_{1}+x_{2}+x_{3}+\cdots+x_{n}\right)
$$

Where:

$\overline{\mathrm{x}}=$ arithmetic mean,

$\mathrm{n}=$ number of values of the selection set,

$\mathrm{x}=$ individual values of the set.

The value of arithmetic mean enables to calculate the value of standard deviations. For this calculation, however, it is necessary to know another value, namely the sample variance. The value of this calculation tells you how varied the values are from the mean of the sample data set. The sample variance can be calculated by the following relation (Neubaeur et al., 2016).

$$
s^{2}=\frac{1}{n} \sum_{i=1}^{n}\left(x_{i}-\bar{x}\right)^{2}
$$

Where:

$\mathrm{s}^{2}=$ sampling variance,

$\mathrm{x}_{\mathrm{i}}=$ individual values of the set,

$\overline{\mathrm{x}}=$ arithmetic mean.

The next important value, which must be found out for the calculation, is the standard deviation of the set. This is actually the average deviation of the set from the average value. The standard deviation can be calculated in the following manner (Neubaeur et al., 2016).

Where:

$$
\sigma=\sqrt{s^{2}}
$$

$\sigma=$ standard deviation,

$\mathrm{s}^{2}=$ dispersion of the set.

In the case that the above-mentioned characteristics are known and the basic null hypothesis $\mathrm{H}_{0}$ and its counterpart, the alternative hypothesis $\mathrm{H}_{a}\left(\mu_{0}\right)$, were set, it is possible to commence the calculation of the one-sample t-test. It tests whether the mean value of the given sample is equal to the set null hypothesis. Before testing, it is necessary to determine the level of significance of the one-sample t-test. In this case, the significance level of $95 \%$ will be used. The specific relation of the one-sample t-test is as follows (Dalgaard, 2008).

$$
t=\frac{\bar{x}-\mu_{0}}{\sigma} \sqrt{n}
$$


Where:

$\mathrm{t}=$ value of one-sample $\mathrm{t}$-test,

$\overline{\mathrm{x}}=$ arithmetic mean,

$\mu_{0}=$ set null hypothesis,

$\sigma=$ standard deviation,

$\mathrm{n}=$ number of values of selection set.

The next step is comparing the resulting value of one-sample t-test with the table of critical values for dividing one-sample t-test. If the resulting value of the one-sample t-test in absolute value is outside a certain range of the $95 \%$ significance level, the value of which was obtained from the tables of critical values, the null hypothesis can be rejected.

\section{Results}

Null hypothesis $\mu_{0}:$ Small enterprises, less than 50 employees, find the administrative intensity in business demanding at the rate of 70\%. Middle-sized enterprises find the administrative intensity in business demanding at the rate of $70 \%$ (comparison).

During verifying the hypothesis simple arithmetic mean must be primarily calculated. There was a total of 95 companies with less than 50 employees and they are classified as small, and the sum of the values of their answers was 291. Enterprises answered on a point scale of $1-4$, where a value of 1 means approximately $25 \%$ intensity and a value of 4 indicates the highest intensity, i.e. $100 \%$.

$$
\bar{x}_{1}=\frac{1}{95}(291)=3.06 \text { point }=76.6 \%
$$

The enterprises having 50 employees and more, therefore, they are regarded as middlesized, were 76 in total. The sum of the responded values by them was 235 .

$$
\bar{x}_{2}=\frac{1}{76}(235)=3.09 \text { point }=77.3 \%
$$

In the next step, it is necessary to calculate the sampling variance of both variables $s_{1}^{2}$ and $s_{2}^{2}$.

$$
\begin{aligned}
& s_{1}^{2}=\frac{1}{95} *\left(x_{1}-3.06\right)^{2}+\left(x_{2}-3.06\right)^{2}+\cdots\left(x_{n}-3.06\right)^{2}=0.65 \\
& s_{2}^{2}=\frac{1}{76} *\left(x_{1}-3.09\right)^{2}+\left(x_{2}-3.09\right)^{2}+\cdots\left(x_{n}-3.09\right)^{2}=0.5
\end{aligned}
$$

If there is available a value informing about the dispersions of both sets, it is possible commence calculating the standard deviation for both sets.

$$
\begin{aligned}
& \sigma_{1}=\sqrt{0.65}=0.81 \\
& \sigma_{2}=\sqrt{0.5}=0.71
\end{aligned}
$$


At this point, all the necessary information for calculating the t-test itself are known. The hypothesis stating that enterprises find administrative intensity demanding at the rate of $70 \%$ must be transfer to a point evaluation. $70 \%$ will be 2.8 points in this case.

$$
\begin{aligned}
& t_{1}=\frac{3.06-2.8}{0.81} \sqrt{95}=3.18 \\
& t_{2}=\frac{3.09-2.8}{0.71} \sqrt{76}=3.56
\end{aligned}
$$

Critical values were selected from the tables for the selections that are calculated. In the first case, the tested set has 96 values. In the tables only the values for the sets with either 90 or 100 samples can be found. Since the value for 100 samples is closer to the set of 96 samples, this will be selected. The critical value for 100 samples is 1.984 . The critical value for the second set of the size 76 values is 1.99 . The values of the calculated t-tests are 3.18 and 3.56. Given that both values are greater than the critical value of 1.984 and 1.99, respectively, both hypotheses at the $95 \%$ level of significance can be rejected, with the proviso that companies do not find the administrative intensity of business as demanding as $70 \%$. This result is confirmed by p-values of the tests that were obtained by the statistical R Commander software as well.

$$
\begin{aligned}
& p-\text { value }_{1}=0.002071=0.2 \% \\
& p-\text { value }_{2}=0.0006459=0.06 \%
\end{aligned}
$$

Both p-values are smaller than $5 \%$ and that is why the rebuttal of each hypothesis is confirmed. Another confirmation is the $95 \%$ quartile obtained by the software, which for the first hypothesis is from 2.9 to 3.23 and for the second hypothesis from 2.93 to 3.26 . These hypotheses, $70 \%$, i.e. 2.8 points, do not fall within these ranges, and so the hypotheses can be disproved in this way. In addition, in the final assessment, it can be stated that businesses with more employees find the administrative intensity of business more demanding than businesses with fewer employees. The results are also confirmed by graph 2 . 
Graph 2: Hypothesis 1 - Gaussian curve of normal division
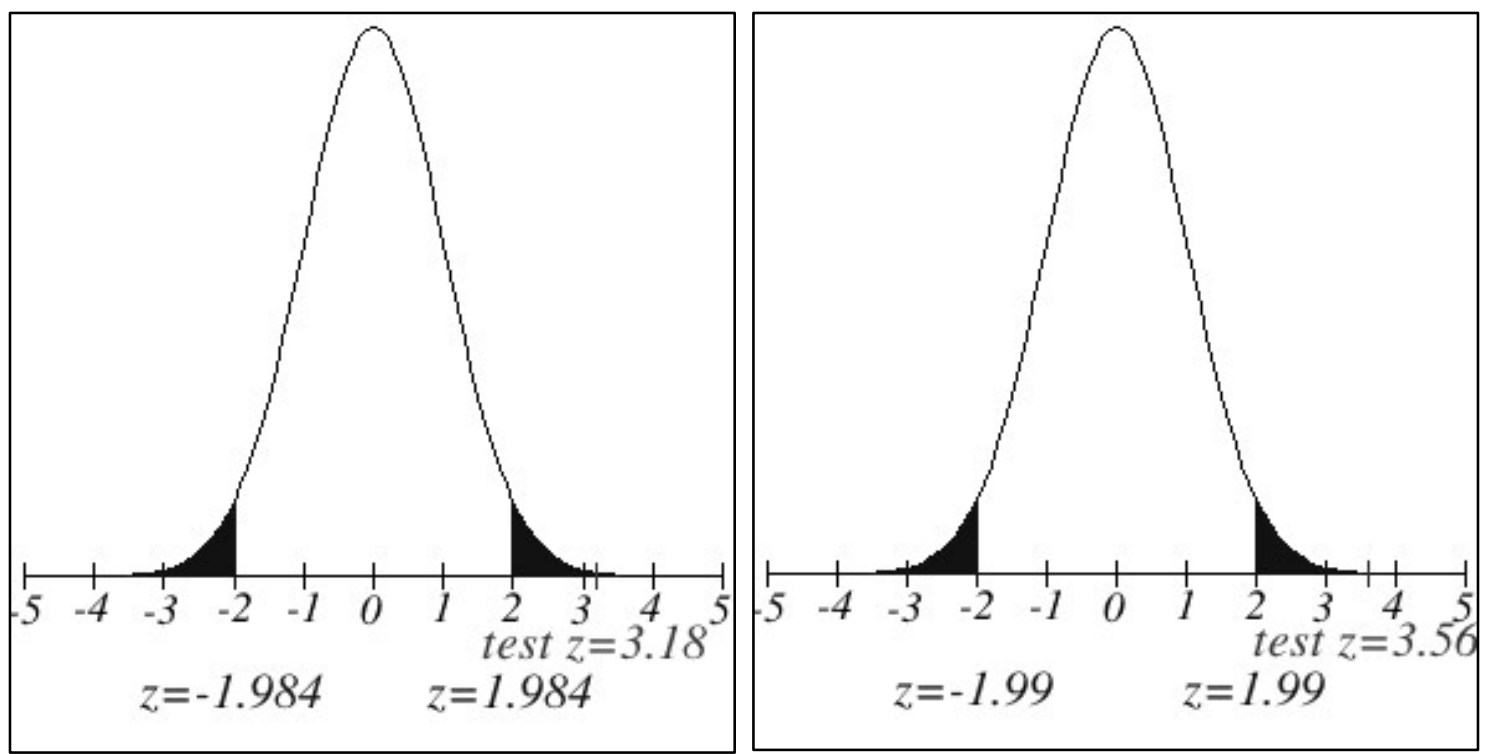

Source: Authors, imathas.com.

Null hypothesis $\mu$ : The enterprises with a turnover of CZK 52 million or less find the administrative intensity of business demanding at the rate of $70 \%$. The enterprises with a turnover more than CZK 52 million find the administrative intensity of business demanding at the rate of $70 \%$. (comparison)

$$
\begin{gathered}
\bar{x}_{1}=\frac{1}{108}(331)=3.06 \text { point }=76.62 \% \\
\bar{x}_{2}=\frac{1}{58}(180)=3.1 \text { point }=77.59 \% \\
s_{1}^{2}=\frac{1}{108} *\left(x_{1}-3.06\right)^{2}+\left(x_{2}-3.06\right)^{2}+\cdots\left(x_{n}-3.06\right)^{2}=0.62 \\
s_{2}^{2}=\frac{1}{58} *\left(x_{1}-3.1\right)^{2}+\left(x_{2}-3.1\right)^{2}+\cdots\left(x_{n}-3.1\right)^{2}=0.54 \\
\sigma_{1}=\sqrt{0.62}=0.79 \\
\sigma_{2}=\sqrt{0.54}=0.73 \\
t_{1}=\frac{3.06-2.8}{0.79} \sqrt{108}=3.42 \\
t_{2}=\frac{3.1-2.8}{0.73} \sqrt{58}=3.13
\end{gathered}
$$

Now, it is necessary to compare the test values with the critical values from the tables. The critical value for the sample of 108 enterprises is 1.96. The critical value for the sample of 58 enterprises is 2 . Both test values are higher than the given critical values; therefore, it is possible to disprove both hypotheses again. 


$$
\begin{aligned}
& p-\text { value }_{1}=0.0007=0.07 \% \\
& p-\text { value }_{2}=0.002=0.2 \%
\end{aligned}
$$

Considering the fact that both $\mathrm{p}$ values are less than $5 \%$ it is possible to confirm in this manner as well that both null hypotheses were disproved and are invalid. This fact can also be proved by checking $95 \%$ of the quartiles of both selections. The $95 \%$ quartile for the first selection is from 2.91 to 3.22 and the $95 \%$ for the second selection is from 2.91 to 3.3. These hypotheses, i.e. 2.8 points, do not fit into the quartile, so it is possible to decide on their invalidity in this way. Moreover, it is possible to deduce from the test values that enterprise with a turnover over CZK 52 million find the administrative intensity more intensive than the enterprises with a turnover of CZK 52 million or less. The results are also confirmed by graph 3 .

Graph 3: Hypothesis 2 - Gaussian curve of normal division

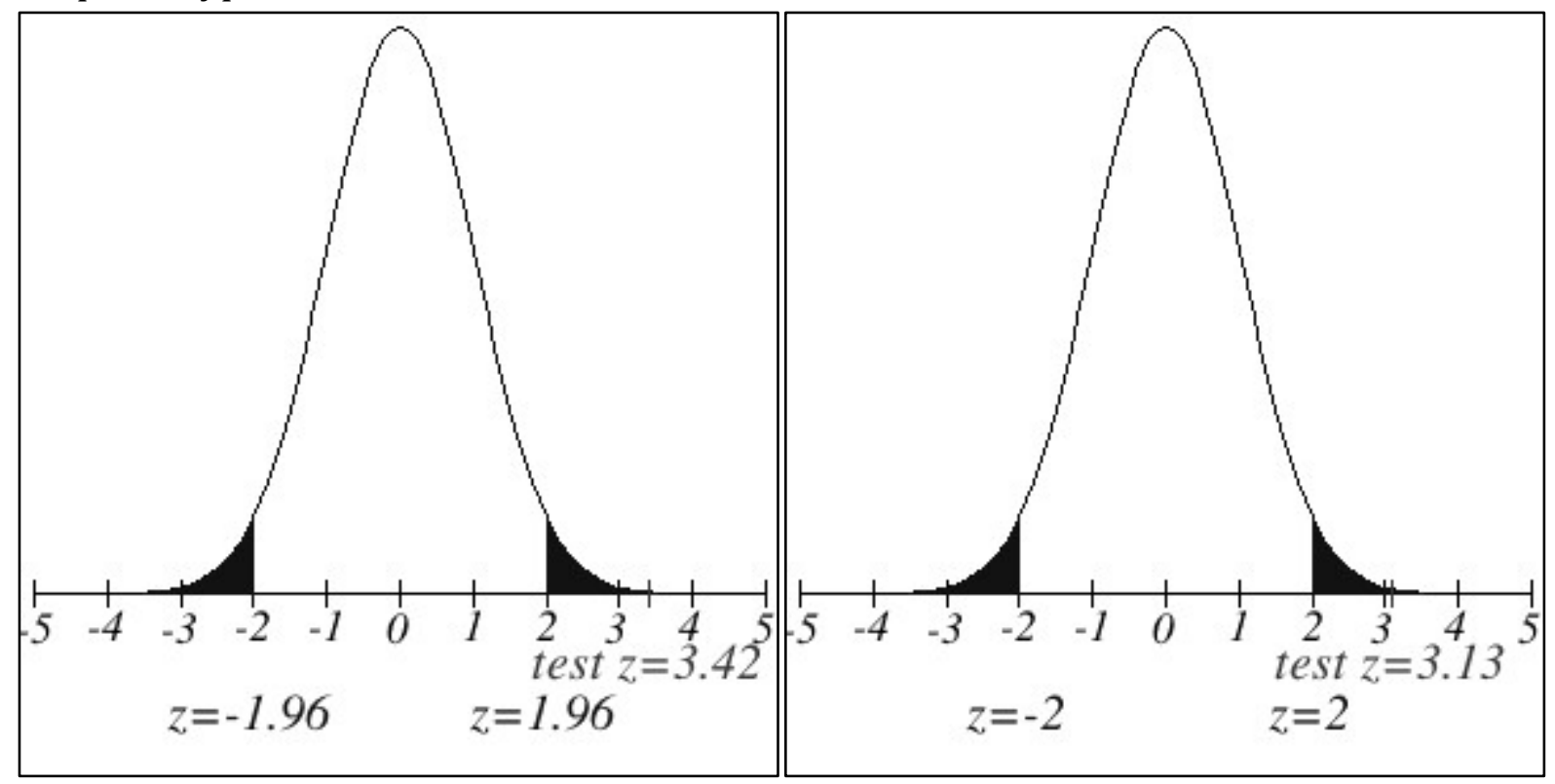

Source: Authors, imathas.com.

Null hypothesis $\mu_{0}$ : Small and middle-sized enterprises in the primary and secondary sectors find the administrative intensity of business demanding at the rate of 70\%. Small and middle-sized enterprises in the tertiary sector find the administrative intensity of business demanding at the rate of $70 \%$. (comparison)

$$
\begin{gathered}
\bar{x}_{1}=\frac{1}{69}(216)=3.13 \text { point }=78.26 \% \\
\bar{x}_{2}=\frac{1}{97}(297)=3.06 \text { point }=76.55 \% \\
s_{1}^{2}=\frac{1}{59} *\left(x_{1}-3.13\right)^{2}+\left(x_{2}-3.13\right)^{2}+\cdots\left(x_{n}-3.13\right)^{2}=0.49 \\
s_{2}^{2}=\frac{1}{97} *\left(x_{1}-3.06\right)^{2}+\left(x_{2}-3.06\right)^{2}+\cdots\left(x_{n}-3.06\right)^{2}=0.64
\end{gathered}
$$




$$
\begin{gathered}
\sigma_{1}=\sqrt{0.49}=0.7 \\
\sigma_{2}=\sqrt{0.64}=0.8 \\
t_{1}=\frac{3.13-2.8}{0.7} \sqrt{69}=3.92 \\
t_{2}=\frac{3.06-2.8}{0.8} \sqrt{97}=3.2
\end{gathered}
$$

At this moment, it is necessary to compare the test values with the critical values from the tables. The critical value for the sample of 69 enterprises is 1.994. The critical value for the sample of 97 enterprises is 1.984. Both test values are higher than the given critical values; therefore, it is possible to disprove both hypotheses again. In addition, this statement can be verified by examining the p-values of both samples, which were obtained by the use of software.

$$
\begin{aligned}
& p-\text { value }_{1}=0.0002=0.02 \% \\
& p-\text { value }_{2}=0.002=0.2 \%
\end{aligned}
$$

Both given p-values of the sample sets are less than $5 \%$, therefore, it is possible to confirm the refusal of both hypotheses. This statement can be confirmed by another method, i.e. with the use of $95 \%$ quartile selections. The $95 \%$ quartile for the first selection, i.e. the enterprises operating in the primary and secondary sectors, is from 2.96 to 3.3 and the $95 \%$ quartile for the second selection, i.e. the enterprises operating in the tertiary sector, is from 2.9 to 3.22. It is obvious that the examined value of hypothesis, i.e. 2.8 points, does not fit into any quartile; therefore, both hypotheses can be deemed invalid. There is a further finding; the enterprises in both the primary and the secondary sector find the administrative intensity of business more demanding than the enterprises in the tertiary sector. The results are also confirmed by graph 4 .

Graph 4: Hypothesis 3 - Gaussian curve of normal division

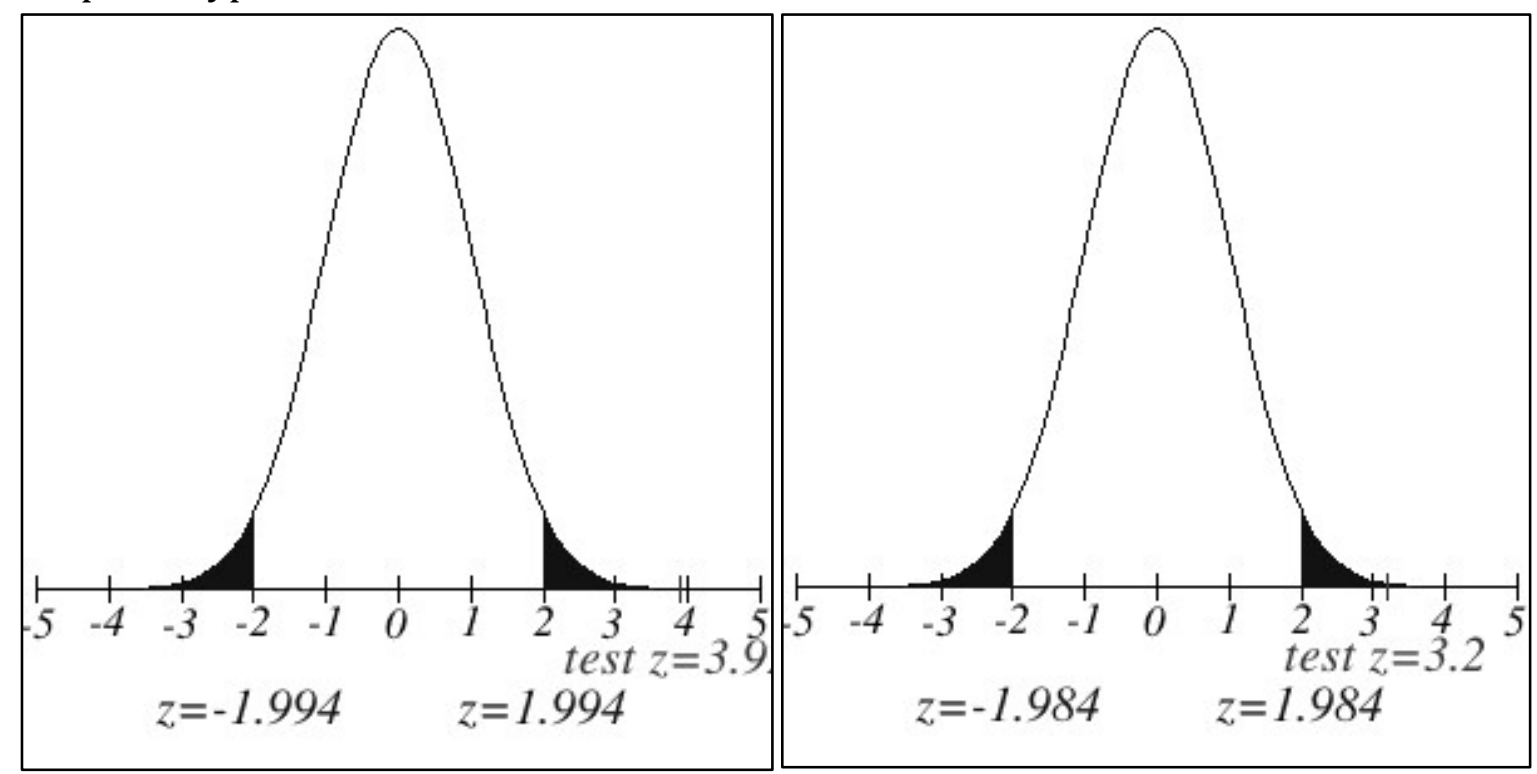

Source: Authors, imathas.com. 
Null hypothesis $\mu_{0}$ : The enterprises with a turnover of CZK 52 million or less find the tax burden (income tax, value added tax, excise duty, road tax) demanding at the rate of $60 \%$. The enterprises with a turnover over CZK 52 million find the tax burden demanding at the rate of $60 \%$. (comparison)

In this case it will be an assessment and comparison of hypothesis examining tax intensity. The enterprises responded on the scale from 1 to 4 points, where 1 point equalled a slight intensity and 4 points equal an inappropriate intensity. The given hypothesis examines a $60 \%$ intensity, which equal the value of 2.4 points. Various points of the responds of the individual types of taxes were made average.

$$
\begin{gathered}
\bar{x}_{1}=\frac{1}{110}(276.5)=2.51 \text { point }=62.75 \% \\
\bar{x}_{2}=\frac{1}{58}(138.25)=2.38 \text { point }=59.5 \% \\
s_{1}^{2}=\frac{1}{110} *\left(x_{1}-2.51\right)^{2}+\left(x_{2}-2.51\right)^{2}+\cdots\left(x_{n}-2.51\right)^{2}=0.57 \\
s_{2}^{2}=\frac{1}{58} *\left(x_{1}-2.38\right)^{2}+\left(x_{2}-2.38\right)^{2}+\cdots\left(x_{n}-2.38\right)^{2}=0.47 \\
\sigma_{1}=\sqrt{0.57}=0.75 \\
\sigma_{2}=\sqrt{0.47}=0.69 \\
t_{1}=\frac{2.51-2.4}{0.75} \sqrt{110}=1.54 \\
t_{2}=\frac{2.38-2.4}{0.69} \sqrt{58}=-0.22
\end{gathered}
$$

If both values of statistical t-tests are calculated, the last step to determine the hypothesis to be valid or invalid is absent; it is the comparison of the resulting values from the t-tests with the critical values from the tables. The critical value for the selection of 110 samples, like in the case of the first hypothesis, is 1.96 . Considering the fact that the critical value of 1.96 is greater than the calculated value of the t-test of 1.54 , it is possible to state that the first hypothesis is valid. In the second case, the critical value of the set of 58 samples equals 2 . Even in this case, the critical value of 2 is higher than the value of the t-test, i.e. 2.22; therefore, the second hypothesis can be deemed as valid as well.

The statement that both hypotheses are valid, can be confirmed by another way; it is with the values found by the software.

$$
\begin{aligned}
& p-\text { value }_{1}=0.11=11 \% \\
& p-\text { value }_{2}=0.86=86 \%
\end{aligned}
$$

As expected, both p-values are higher than 5 and it is possible to confirm the validity of both hypothesis in this way as well.

The validity of the hypothesis can be verified by yet another method, i.e. by a $95 \%$ quartile of the sets. It was found out by the software. The $95 \%$ quartile for the first selection, i.e. 
for the enterprises with a turnover of CZK 52 million, is from 2.37 to 2.66. The above given calculated arithmetic mean at the value of 2.21 fits into this range and the validity of the hypothesis is confirmed in this way as well. The $95 \%$ quartile for the second selection, the enterprises with a turnover over CZK 52 million, is from 2.2 to 2.56 . The above calculated value of the arithmetic mean for this selection was 2.38 . This value, like in the case of the first selection, fits into the $95 \%$ quartile and, therefore, the accuracy of the statement is confirmed for the second selection as well. The results are also confirmed by graph 5 .

Graph 5: Hypothesis 4 - Gaussian curve of normal division
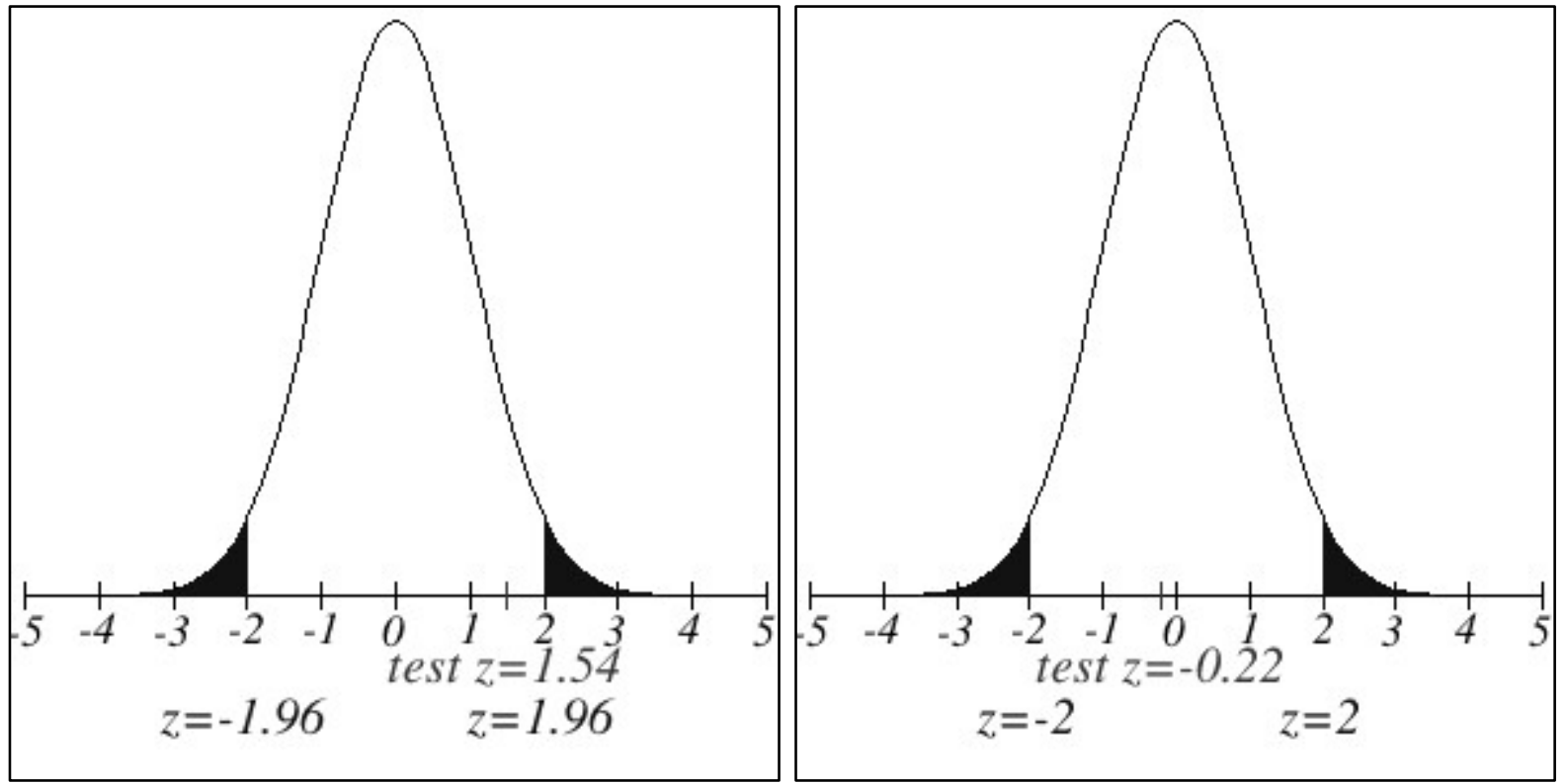

Source: Authors, imathas.com.

\section{Discussion}

All results of the paper, which are clearly shown in table 1, were further verbally commented.

Tab. 1: Summary assessment of the hypothesis

\begin{tabular}{|c|c|c|c|}
\hline Hypothesis & t-test value & Critical value & Result \\
\hline $\mathrm{H}_{1}$ & 3.18 and 3,56 & 1.984 and 1,99 & Hypothesis disproved \\
\hline $\mathrm{H}_{2}$ & 3.42 and 3,13 & 1.96 and 2,0 & Hypothesis disproved \\
\hline $\mathrm{H}_{3}$ & 3.92 and 3,2 & 1.994 and 1,984 & Hypothesis disproved \\
\hline $\mathrm{H}_{4}$ & 1.54 and $-0,22$ & 1.96 and 2,0 & Hypothesis proven \\
\hline
\end{tabular}

Source: Authors. 
Null hypothesis $\mu_{0}:$ Null hypothesis $\mu_{0}:$ Small enterprises, with less than 50 employees, find the administrative intensity in business demanding at the rate of $70 \%$. Middle-sized enterprises find the administrative intensity in business demanding at the rate of $70 \%$ (comparison).

The first hypothesis examined, whether the enterprises, which were divided, in accordance to the number of the employees, into the small (50 employees or less) and middle-sized ( 250 employees or less), bear the administrative intensity in business at the rate of $70 \%$ and, subsequently, it was planned to compare the results and find out, if there is a difference depending on the size of the enterprise in terms of administrative intensity. It was found out that none of the given selections bear the administrative intensity in business at the rate of $70 \%$. The administrative intensity was in much higher numbers, slightly above $75 \%$. It was discovered during the comparison that although the administrative intensity is demanding for the enterprises, the size of the enterprise does not mean a difference.

Null hypothesis $\mu_{0}$ : The enterprises with a turnover of CZK 52 million or less find the administrative intensity in business demanding at the rate of $70 \%$. The enterprises with a turnover over CZK 52 million find the administrative intensity in business demanding at the rate of $70 \%$. (comparison)

The second hypothesis had a task to examine, whether the enterprises, divided in accordance to the size of turnover, specifically of CZK 52 million or less and over CZK 52 million, are taxed slightly or significantly; subsequently it was necessary to compare both detected results and state, whether the size of turnover means a difference at this rate. The given results show that the enterprises, divided in accordance to their turnover, do not bear an administrative burden at the rate of $70 \%$, but much higher, specifically of $76.6 \%$ and $77.6 \%$. Both hypotheses were, therefore, disproved. During comparing the enterprises with a turnover of CZK 52 million or less and over CZK 52 million, it was found out that the criterion of turnover is not substantially significant in terms of their administrative burden.

Null hypothesis $\mu_{0}$ : Small and middle-sized enterprises in the primary and secondary sectors find the administrative intensity of business demanding at the rate of $70 \%$. Small and middle-sized enterprises in the tertiary sector find the administrative intensity of business demanding at the rate of $70 \%$. (comparison)

The third hypothesis examined the administrative intensity in business and the standard was a type of sector that they operated in. Specifically, the enterprises were divided into two groups. The first group involved the enterprises operating in the primary and secondary sectors. The second involved the enterprises operating in the tertiary sector. It was found out that the enterprises divided in accordance to a sector do not bear the administrative intensity at the rate of $70 \%$. The burden is higher for the enterprises, specifically $78.3 \%$ and $76.6 \%$. It was found out during the comparison that the enterprises operating in the primary and secondary sectors show a slightly higher burden than the 
enterprises operating in the tertiary sector. This may be caused by the mode and complexity of production, which does not exist in the tertiary sector.

Null hypothesis $\mu_{0}$ : The enterprises with a turnover of CZK 52 million or less find the tax burden (income tax, value added tax, excise duty, road tax) demanding at the rate of $60 \%$. The enterprises with a turnover over CZK 52 million find the tax burden demanding at the rate of $60 \%$. (comparison)

The last hypothesis dealt with the tax intensity of enterprises. The enterprises were divided again, in accordance to their turnover this time, and the extent of their tax burden was examined; as well as whether the turnover meant any difference in the burden. It was found out that the enterprises, divided in accordance to a turnover, are taxed at the rate of $62.8 \%$, or at $59.5 \%$ respectively. In this case, the hypothesis stating the enterprises, divided in accordance to a turnover, are taxed at the rate of $60 \%$, was proven in both selections. Surprising results were provided by the following comparison. It was discovered that the enterprises disposing of a turnover of CZK 52 million and less are taxed more than the enterprises disposing of a turnover over CZK 52 million, the difference is about $3 \%$.

\section{Conclusion}

Finally, we can conclude: There was a set of enterprises. They were divided in accordance to several standards and underwent a statistical analysis; statements were set by the use of hypothesis and it was necessary to prove or disprove them. The hypothesis related to the administrative intensity in business of small and middle-sized enterprises. The specific divisions were formed by the standards based on the size, number of employees, size of turnover and the sector in which the enterprise operated. The additional hypothesis related to the tax intensity of small and middle-sized enterprises. It was recommended to prove or disprove the hypothesis on the base of comparing the test values with the critical values. This recommendation was verified by other ways; i.e. the setting of hypothesis on the basis of p-value and a 95\% quartile. The hypothesis were set that the administrative intensity in business of small and middle-sized enterprises is demanding for them at the rate of $70 \%$, however, they were disproved in every case; it was found out that the intensity is much higher and oscillates roughly around $75-80 \%$. The purpose of the paper was fulfilled, it was proven and shown that small and middlesized enterprises bear excessive administrative intensity and it is necessary to deal with this problem more in the future to find appropriate measures which will ease the administration for the enterprises and allow them to conduct their business more. The additional hypothesis related to tax intensity stated that small and middle-sized enterprises bear the tax burden at the rate of $60 \%$. This hypothesis was proven. All the statements were displayed in the appropriate graph depicting a Gaussian curve. 


\section{Acknowledgement}

The data for this paper were obtained during the scientific activity in the Institute of Technology and Business in Ceske Budejovice; Project TL01000349 Stabilisation and development SME in the rural area, TA CR - Eta program.

\section{References}

1. An Internet Mathematics Assessment System [online]. [accessed: 2020-05-10]. Available from: http://www.imathas.com/

2. BRAUNERHJELM, P., J. E. EKLUND, 2014. Daně, daňová administrativní zátěž a vznik nové firmy [Taxes, tax administrative burden and the creation of a new company]. Kyklos. 67(1), 1-11.

3. BUDÍKOVÁ, M. et al., 2010. Průvodce základními statistickými metodami [Guide to basic statistical methods]. Praha: Grada. ISBN 978-80-247-3243-5.

4. ČEPEL, M. et al., 2018. Business environment quality index in the SME segment. Journal of Competitiveness. ISSN 1804-171X.

5. DALGAARD, P., 2008. Introductory Statistics with R. New York: Springer. ISBN 9780-387-79053-4.

6. FIFKA, M., C. R. L. ADAUI, 2015. Corporate Social Responsibility (CSR) Reporting Administrative Burden or Competitive Advantage? In: New Perspectives on Corporate Social Responsibility. Springer Gabler, Wiesbaden, 285-300. ISBN 978-3658-06794-6.

7. HODINKOVÁ, M., P. VIRÁK, 2014. Barriers to Development of SMEs. Trends Economics and Management. 7(17), 61-67. ISSN 1802-8527.

8. KAMIL, D. et al., 2017. The perception of governmental support in the context of competitiveness of SMEs in the Czech Republic. Journal of Competitiveness. 9(3), 34. ISSN 1804-171X.

9. KMECOVÁ, I., S. BÍLEK, 2020. Legislativně-právní základna a administrativní zátěž MSP [Legislative basis and administrative burden of SMEs]. In: Malé a střední podnikání $v$ České republice - současnost a vize, Praha: Grada Publishing.

10. KLJUCNIKOV, A., M. MAJKOVÁ, 2016. Impact of Gender in the Perception of Administrative Burdens among Young Entrepreneurs-Evidence from Slovakia. Journal of Competitiveness. 8(2), 17-30 ISSN 1804-171X.

11. MOYNIHAN, D. et al., 2015. Administrativní zátěž: Náklady na učení, psychologii a dodržování předpisů v interakcích mezi státem a státem [Administrative burden: Costs for learning, psychology and compliance in state-state interactions]. Journal of Public Administration Research and Theory. 25(1), 43-69. ISSN 1053-1858.

12. MPO ČR, 2018a. Zpráva o vývoji malého a středního podnikání a jeho podpoře v roce 2017 [Report on the development of small and medium-sized enterprises and their support in 2017] [online]. Ministerstvo průmyslu a obchodu, 2018 [accessed: 201811-1] Available from: <https://www.mpo.cz/assets/cz/podnikani/male-a- 
stredni-podnikani/studie-a-strategicke-

dokumenty/2018/10/Zprava_MSP_2017.pdf>

13. NEUBAEUR, J. et al., 2016. Základy statistiky - Aplikace v technických a ekonomických oborech [Basics of statistics - Applications in technical and economic fields]. ISBN 978-80-247-5786-5.

14. NTALIANI, M., C. COSTOPOULOU, 2018. Elektronická vláda pro snižování administrativní zátěže: Empirický výzkum evropských venkovských podniků [Electronic government for reducing administrative burdens: Empirical research on European rural businesses]. International Journal of Public Administration. 41(9), 700-711.

15. NTALIANI, M., C. COSTOPOULOU, 2017. Snížení administrativní zátěže pro malé a střední podniky [Reducing the administrative burden for SMEs]. Administration \& Society. 49(8), 1143-1164.

16. ROPRET, M. et al., 2018. Vnímání administrativních překážek a jejich důsledky pro výkon malých a středních podniků: Důkazy ze Slovinska [Perceptions of administrative barriers and their implications for the performance of SMEs: Evidence from Slovenia]. Záhřeb International Review of Economics \& Business. 5568. ISSN 1849-1162.

17. SARAH, P. et al., 2018. Stejná řeka stejná pravidla - administrativní překážky v dunajských zemích [Same river same rules - administrative barriers in the Danube countries]. Journal of Sustainable Development of Transport and Logistics. 3(3), 2737. ISSN 2520-2979.

18. VEIGA, L. et al., 2016. Digitální správa a snižování administrativní zátěže [Digital administration and reduction of administrative burden]. In: Sborník $z \quad 9$. mezinárodní konference o teorii a praxi elektronické správy. 323-326. Retrieved from: https://doi.org/10.1145/2910019.2910107.

19. VIRGLEROVA, Z. et al., 2016. The perception of the state's influence on its business environment in the SMEs from Czech Republic. Administratie si Management Public. 26, 78-96. ISSN 1583-9583.

20.ŽÁROVÁ, M. et al., 2010 Revize účetních směrnic [Revision of accounting guidelines]. Český finanční a účetní časopis. 7-19. doi: 10.18267/j.cfuc.55.

\section{Contact address of the authors:}

Ing. Iveta Kmecová, PhD., Institute of Technology \& Business in Ceske Budejovice, Faculty of Corporate Strategy, Okruzni 517/10, Ceske Budejovice 37001, Czech Republic, e-mail: kmecova@mail.vstecb.cz

Bc. Michal Tlustý, Institute of Technology \& Business in Ceske Budejovice, Faculty of Corporate Strategy, Okruzni 517/10, Ceske Budejovice 37001, Czech Republic, e-mail: 19838@mail.vstecb.cz 
DOI: https://doi.org/10.36708/Littera_Scripta2020/1/9

Ing. Vendula Velková, Institute of Technology \& Business in Ceske Budejovice, Faculty of Corporate Strategy, Okruzni 517/10, Ceske Budejovice 37001, Czech Republic, e-mail: velkova@mail.vstecb.cz 